\title{
British Thermal Unit 59 Degrees Fahrenheit
}

National Cancer Institute

\section{Source}

National Cancer Institute. British Thermal Unit 59 Degrees Fahrenheit. NCI Thesaurus.

Code C69151.

A non-SI unit of energy equal to the amount of heat required to raise the temperature of one pound avoirdupois of air-free water by one degree Fahrenheit (from 58.5 to 59.5 degrees) at a constant pressure of one atmosphere. The British thermal unit at 59 degrees Fahrenheit is based on the definition of the 15 degrees Celsius calorie (exactly 4.1855 joules) and is equal to approximately $1.054804 \mathrm{~kJ}$. 